\title{
ВИБІР ПРОГРАМНОГО ЗАБЕЗПЕЧЕННЯ ДЛЯ КОМП'ЮТЕРНИХ ВИДАВНИЧИХ СИСТЕМ
}

\author{
( Т. А. Роїк, д.т.н., професор, Д. І. Лемешко, \\ магістрант, НтУУ «КПІ», Київ, Україна
}

\section{Сделан обзор источников, посвященных применению програмного обеспечения для установки на персональные компьютеры, которые интегрированы в компьютерные издательские системы и предложены рекомендации по их эксплуатации.}

It was carried out the review of sources on the application software to be installed to personal computers that are integrated in the computer publishing systems and proposed the recommendations of their exploitation.

\section{Постановка проблеми}

Сучасні комп'ютерні видавничі системи, для якісної і безперебійної роботи, вимагають дотримання чітких правил користування та встановлення програмного забезпечення. Причому важливо не тільки правильно встановити програмний пакет, а і упевнитись у його якості та функціональності. Адже від якості програмного пакету залежить ефективність та коректність всього процесу підготовки до друку накладу. У зв'язку з цим тема роботи актуальна і потребує детальних досліджень.

\section{Аналіз попередніх досліджень}

На даному етапі існують матеріали, що надають рекомендації до використання пакетів програмного забезпечення у комп'ютерних видавничих системах, які нині застарілі, так як використовують програмне забезпечення 2000-2005 років і майже не використовуються.
Темпи розвитку програмного забезпечення нового покоління потребують постійного оновлення як операційних систем так і потужностей функціональних блоків комп'ютера. Виходячи з цього можна зробити висновки, що попередні дослідження не в повному обсязі задовольняють сучасних операторів комп'ютерної видавничої системи [1].

\section{Результати проведених досліджень}

Для додрукарської підготовки видань у роботі було виконано вибір програмного забезпечення, що рекомендується для встановлення на робочі комп'ютери станцій обробки текстової та графічної інформації. Тому детально розглядалась комп'ютерна видавнича система (КBC) та окремі її робочі станції.

КВС складається $з$ декількох видів робочих станцій: РСТ (робочі станції обробки текстової інформації), РСГ (робочі станції обробки графічної інформації), 
РСВ (робочі станції верстання видань), РССФ (робочі станція із суміщенням функцій) та файлового сервера ФС, що показано на рис.

Для кожної з вищезгаданих робочих станцій (рис.) створюється власний пакет прикладних програм, що виконує чіткі функції необхідні для правильної та безперервної роботи станції [2].

Пакети видавничих програм належать до професійного прикладного програмного забезпечення, призначеного для виконання практичних робіт під час додрукарської підготовки видань у КBC.

Для повноцінного функціонування робочої станції з суміщеними функціями для підготовки півтонових брошур необхідне наступне програмне забезпечення: системне програмне забезпечення та прикладне програмне забезпечення. До системного програмного забезпечення відносяться: операційна багатофункціональна система, в базову комплектацію якої також входять драйвери для більшості відомих марок периферійних пристроїв.

Драйвери периферійних пристроїв. В нашому випадку такі периферійні пристрої як ди- сплей, сканер, принтер, клавіатура та маніпулятор «миша», а також HЖМД та CD-RW забезпечені драйверами, які ідуть в базовій комплектації з операційною системою.

До прикладного програмного забезпечення КВС можна включити такі наступні програми:

- Пакет офісних програм Microsoft Office 2009;

- Програма обробки векторної графіки Adobe Illustrator CS4;

- Програма обробки растрової графіки Adobe Photoshop CS5;

- Програма для сканування і розпізнавання тексту ABBYY FineReader 8.0;

- Програма обробки растрової графіки Corel PhotoPaint 13 ;

- Програма обробки векторної графіки CorelDraw 13;

- Пакет програм для перегляду та модифікації файлів у форматі PDF Adobe Acrobat.

Пакети видавничих програм оброблення текстів складаються із сукупності текстових редакторів, програм перевірки правопису, програм перекладу з однієї мови на іншу, програм розпізнавання зчитаних символів тощо [3].

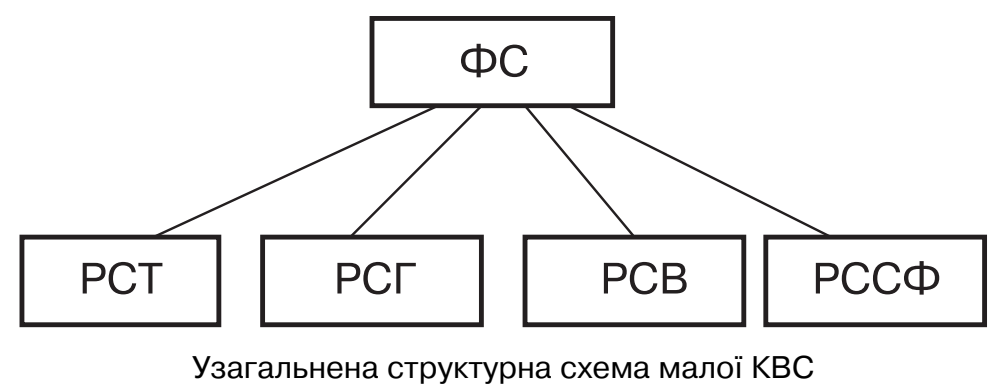


Текстові редактори Microsoft Word забезпечують набір текстів на клавіатурі різними мовами, автоматизовану перевірку орфографії, виконання переносів, а також форматування тексту 3 вибором полів, гарнітури шрифту і його накреслення, кегля тощо.

Крім введення з клавіатури, останнім часом друковані тексти часто вводять за допомогою сканерів, використовуючи програму оптичного розпізнавання символів Fine Reader. Finereader 8.0 дозволяє побудувати бізнес-процеси компанії, орієнтовані на електронний документообіг, організувати роботи зі збору, зберігання й подальшого використання інформації з різних паперових джерел.

В додрукарській підготовці видань широко використовується Adobe Acrobat. За допомогою цієї програми електронні і паперові матеріали, включаючи вебсайти, інженерні креслення і електронні листи можна представити у вигляді PDF-файлів. Програма допоможе налагодити ефективний обмін важливими документами [4].

Графічні редактори - це прикладні програми, які дозволяють вводити або створювати, обробляти або виводити на друк різноманітні графічні зображення - фото, малюнки, креслення, графіки, діаграми, тощо.

Один з найвідоміших графічних редакторів - Adobe Photoshop. Графічний редактор Adobe Photoshop застосовують для ство- рення фотореалістичних зображень, роботи зі сканованими кольоровими зображеннями, ретушування, кольорокорекції, коллажування, трансформації графіки, кольороподілу; має в своєму розпорядженні всі методи роботи з точковими зображеннями, при цьому має можливість роботи з шарами і використовує контури.

Також використовується растровий графічний редактор Corel PhotoPaint 13 та такі відомі векторні графічні редактори як CorelDraw 13 та Adobe Illustrator CS3.

На основі аналізу програмного забезпечення для додрукарської підготовки видань було здійснено вибір програмного забезпечення для ефективної роботи станцій з обробки текстової та графічної інформації, що включає в себе поєднання набору прикладних програм, який здатен сприяти одержанню високих показників якості видань [5].

\section{Висновки}

У світі на даний період часу існує безліч прикладних програм для обробки та редагування електронної інформації, але більшість 3 них потребують тестування на сумісність з операційною системою комп'ютера.

Тому через певні проміжки часу необхідно проводити вибір програмного забезпечення, яке найбільш оптимальне для додрукарської підготовки видань. 
Як показали дослідження, фічної інформації, зокрема, редля забезпечення якості додрукарської підготовки видань необхідно ретельно та відповідально добирати програмні продукти для обробки текстової та гракомендовано поєднання сучасної операційної системи Windows 7 та програми обробки растрової графіки Adobe Photoshop CS5 з пакетом допоміжних програм.

1. Хомяков В. І. Системотехніка автоматизованих видавничо-поліграфічних комплексів : навч. посіб. / В. І. Хомяков. - К. : НТУУ «КПІ», 2009. 252 с. 2. Величко О. Видавничо-поліграфічна справа : Практикум з проектування і розрахунку технологічних і виробничих процесів / Олена Величко [Текст] : навч. посіб. - К. : ВПЦ «Київський університет», 2009. - 520 с. 3. Дорош А. К. Комп'ютеризовані репросистеми, автоматизовані системи переробки текстової та графічної інформації (розробка, проектування, виготовлення, експлуатація, ремонт) : Підручник : у 3 кн. / А. К. Дорош, Л. Д. Шабас. - К. : ВПЦ «Видавництво „Політехніка”», 2002. - Кн. 1. - 320 с. 4. Мартинюк В. Т. Основи додрукарської підготовки образотворчої інформації : підруч. : у 2 кн. - Кн. 1: Основи опрацювання образотворчої інформації / В. Т. Мартинюк. - К. : Варта, 2005. - 240 с. 5. Мартинюк В. Т. Основи додрукарської підготовки образотворчої інформації : підруч. : у 2 Кн. - Кн. 2: Процеси опрацювання образотворчої інформації / В. Т. Мартинюк. - К. : У-т «Україна», 2009. - 291 с. 